\title{
Angiogenesis Inhibitors as Anti-Cancer Therapy Following Renal Transplantation: A Case Report and Review of the Literature
}

\author{
Lawrence Kasherman ${ }^{1} \oplus$, Jeffrey Doi ${ }^{2}{ }^{\circledR}$, Katherine Karakasis ${ }^{1}$, Jeffrey Schiff ${ }^{3}$, \\ Abhijat Kitchlu ${ }^{4}$, Stephanie Lheureux ${ }^{1}$ and Amit M. Oza ${ }^{1, *}$ \\ 1 Princess Margaret Cancer Centre, Bras Family Drug Development Program, Division of Medical \\ Oncology \& Hematology, University Health Network, University of Toronto, Toronto, \\ ON M5G2M9, Canada; Lawrence.Kasherman@health.nsw.gov.au (L.K.); \\ Katherine.Karakasis@Uhn.ca (K.K.); Stephanie.lheureux@uhn.ca (S.L.) \\ 2 Princess Margaret Cancer Centre, Department of Pharmacy, University Health Network, \\ University of Toronto, Toronto, ON M5G2M9, Canada; jeffrey.doi@uhn.ca \\ 3 Toronto Transplant Institute, University Health Network, University of Toronto, \\ Toronto, ON M5G2C4, Canada; jeffrey.schiff@uhn.ca \\ 4 Division of Nephrology, University Health Network, University of Toronto, Toronto, \\ ON M5G2C4, Canada; Abhijat.Kitchlu@uhn.ca \\ * Correspondence: Amit.Oza@uhn.ca; Tel.: 416-946-4450; Fax: 416-946-4467
}

Received: 2 November 2020; Accepted: 15 January 2021; Published: 22 January 2021

\begin{abstract}
Solid organ transplant recipients on long-term immunosuppressive medication are at increased risk of developing malignancy, and treatment of advanced cancers with angiogenesis inhibitors in this context has not been widely studied. We present a case of recurrent high-grade serous ovarian carcinoma treated with paclitaxel and bevacizumab in the context of prior renal transplantation where the patient responded well to treatment with controlled toxicities, discussing the potential for increased rates of adverse events and drug interactions in this select population.
\end{abstract}

Keywords: bevacizumab; vascular endothelial growth factor; angiogenesis inhibitor; transplant; proteinuria; nephrotoxicity; case report

\section{Introduction}

Angiogenesis inhibitors such as vascular endothelial growth factor (VEGF) monoclonal antibodies and tyrosine kinase inhibitors (Figure 1) are standard treatments across various cancer subtypes. In advanced high-grade serous ovarian cancer (HGSOC), bevacizumab is part of the standard of care as maintenance therapy in front-line and recurrent disease [1]. Although the toxicity profile is generally well-managed, nephrotoxicity manifesting as proteinuria remains an important adverse event that requires close monitoring [2]. There is limited literature surrounding angiogenesis inhibitors as anti-cancer treatment in patients who have received solid organ transplants, and thus this report presents a case demonstrating safety of angiogenesis inhibition as anti-cancer therapy in a patient with a stable renal transplant. 


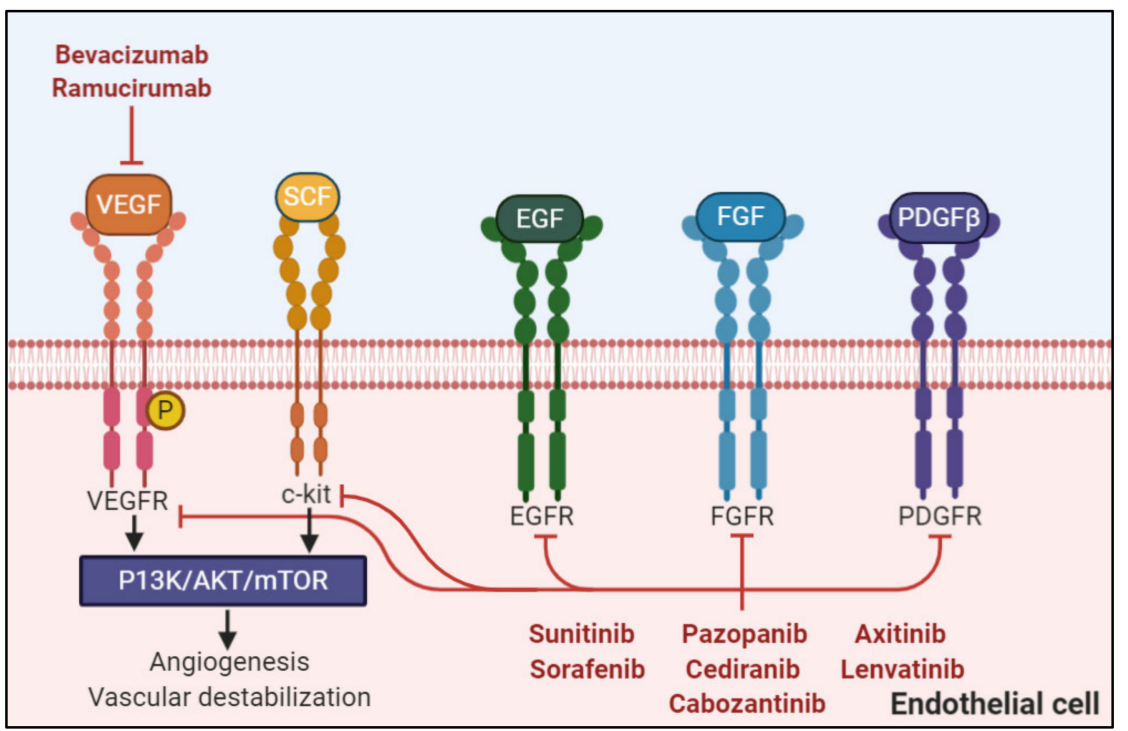

Figure 1. Angiogenesis pathways in malignancy and targeted therapies commonly used. Monoclonal antibodies including bevacizumab and ramucirumab and tyrosine kinase inhibitors including sunitinib, sorafenib, lenvatinib, pazopanib, axitinib, cediranib, and cabozantinib have been included (this list is not exhaustive). Receptors including VEGFR, c-kit, epidermal growth factor receptor (EGFR), fibroblast growth factor receptor (FGFR), and PDGFR are displayed here, but certain medications also target other pathways not displayed here such as AXL and RET. The VEGFR pathway intersects with multiple cell signaling pathways, including the PI3K/AKT/mTOR pathway. Created with Biorender.com.

\section{Case Description}

Consent: Fully informed, voluntary, written consent has been obtained to include patient information and publish this report.

Ethics: As this is a case report with fewer than three patients, institutional approval was not sought as per the University Health Network Research Ethics Board guidance document on case reports.

A 47-year-old woman presented with several months of dyspnea and abdominal distension to Princess Margaret Cancer Centre in February 2019 (Figure 2). CT revealed a $13.9 \mathrm{~cm}$ pelvic mass with peritoneal carcinomatosis and ascites. Omental biopsy confirmed HGSOC, and she received neoadjuvant platinum-based chemotherapy with excellent tolerance and no renal complications before proceeding to interval debulking in June 2019. There was no visible residual disease, and diagnosis of HGSOC was confirmed, germline and somatic BRCA wild type. She completed three cycles of adjuvant chemotherapy.

Her background was significant for IgA nephropathy, which resulted in progressive chronic kidney disease for 18 years prior to living donor kidney transplant in 2016. Both she and her donor were cytomegalovirus-positive, and she developed cytomegalovirus-associated colitis shortly post-transplantation. Her initial immunosuppression consisted of basiliximab induction followed by tacrolimus, mycophenolic acid, and steroids. She developed antibody-mediated rejection one week post-transplant, which was treated with plasmapheresis, immunoglobulin, and an increase in steroid dose. This was repeated three months later due to biopsy confirming ongoing antibody-mediated rejection. Mycophenolic acid was stopped upon HGSOC diagnosis. She has remained medication-adherent, with regular serum tacrolimus levels within the target range (most recently, 5.3 micrograms/L) and no signs of chronic graft rejection.

Her other comorbidities include diet-controlled, steroid-induced diabetes mellitus; ductal breast carcinoma in situ requiring wide local excision in 2011; asthma; reflux disease; hypertension; and hyperlipidemia. Other medications include prednisone $5 \mathrm{mg}$ daily, acetylsalicylic acid, bisoprolol, trimethoprim-sulfamethoxazole, vitamin $\mathrm{D}$, and inhaled salbutamol as needed. 


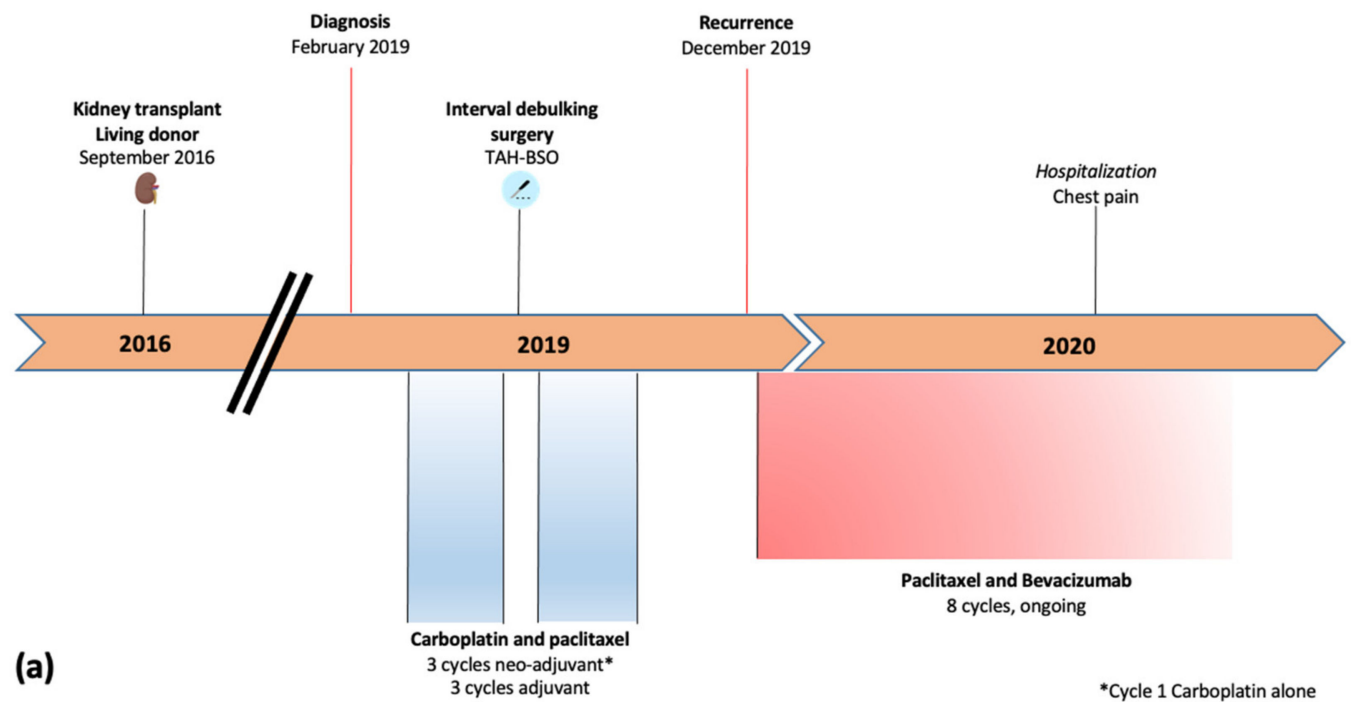

(b)

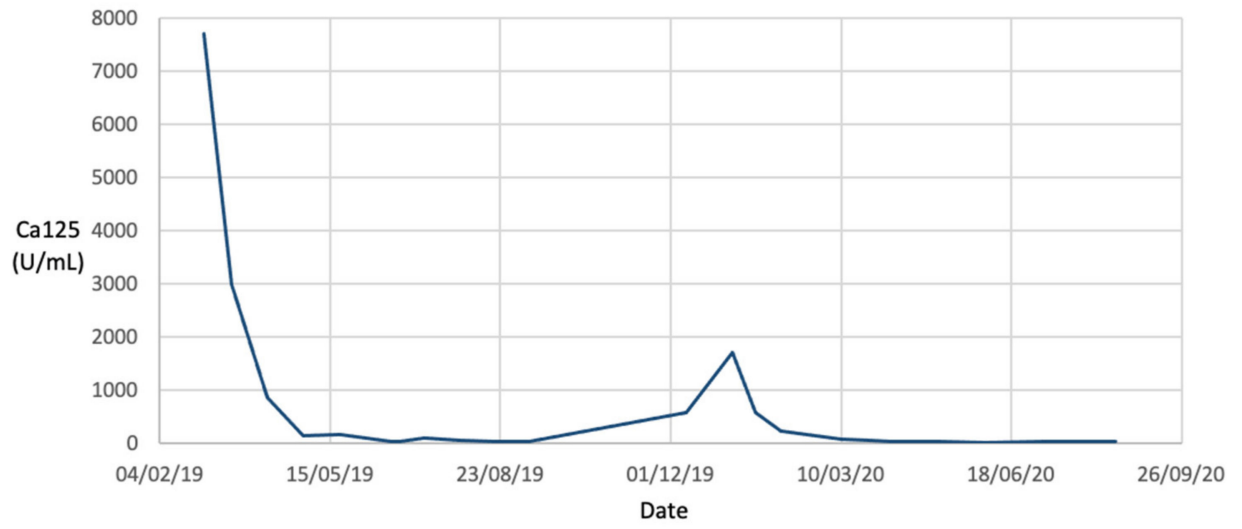

Figure 2. (a) Summary oncology treatment timeline. (b) Ca125 trend from diagnosis to current.

In December 2019, she developed recurrence in the peritoneum and retroperitoneal lymph nodes, signifying platinum resistance. In January 2020, she commenced weekly paclitaxel $80 \mathrm{mg} / \mathrm{m}^{2}$ with bevacizumab $10 \mathrm{mg} / \mathrm{kg}$ every two weeks, and at that time, tacrolimus dose was reduced to $2 \mathrm{mg}$ daily to aim for a serum level of 5 micrograms/L. She continued this therapy for over 6 months, and continued on the same dose of immunosuppression throughout with tacrolimus levels ranging between 3 and 7.6 micrograms/L. Serial imaging and Ca125 confirmed good response to treatment with reduction in size of tumor deposits. Her albumin/creatinine ratio was normal at 0.9 prior to the diagnosis of ovarian cancer, and most recently has been 15.6, signifying microalbuminuria; this has been monitored via urinalysis, which has consistently reported protein as negative or trace. Her most recent estimated glomerular filtration rate was $55 \mathrm{~mL} / \mathrm{min}$, similar to pre-diagnosis, and creatinine levels have mostly fluctuated between 95 and $120 \mu \mathrm{mol} / \mathrm{L}$.

Her course has been complicated by grade 2 hypertension (up to 145/95 $\mathrm{mmHg}$ ) and non-cardiac chest pain, for which amlodipine was switched to ramipril $10 \mathrm{mg}$ daily, and bevacizumab was withheld on two different occasions. Furthermore, she developed a brief period of Kidney Disease: Improving Global Outcomes (KDIGO) stage 1 acute kidney injury (AKI) of pre-renal etiology in September 2020 with creatinine of $160 \mu \mathrm{mol} / \mathrm{L}$, which self-resolved following withdrawal of bevacizumab, and was resumed after a 1-month-long break with no further episodes of kidney injury. 


\section{Discussion}

Nephrotoxicity with angiogenesis inhibitors is relatively common, with proteinuria occurring in over $60 \%$ of patients [2]. Most cases are low-grade, transient, and do not require interventions or dose delays; however, more persistent, severe cases presenting as AKI and nephrotic syndrome can occur [2,3]. Risk factors associated with high-grade proteinuria include increased dose, prolonged administration, pre-existing renal disease, and administration of concurrent chemotherapy [4,5].

The pathophysiology of VEGF inhibitor-induced proteinuria remains unclear. Within a normal kidney, VEGF is produced by podocytes, and VEGF receptors are typically present on the glomerular and peritubular endothelium in addition to mesangial cells [6]. Inhibition of VEGF is thought to cause loss of endothelial fenestrations, podocyte injury and reduce endothelial proliferation, ultimately causing disruption of glomerular membranes [6]. Some cases have also demonstrated subacute thrombotic microangiopathy with endotheliosis and membranoproliferative changes [7]. Another manifestation of nephrotoxicity that is commonly seen is hypertension, occurring in more than a third of patients, which arises due to various mechanisms of renal vascular injury including inhibition of nitric oxide, rarefaction of microvasculature, and neuroendocrine dysregulation [8,9]. It is also hypothesized to increase intraglomerular pressure and ultrafiltration, leading to proteinuria [10].

The lack of clarity surrounding pathophysiology of VEGF inhibitor-induced nephrotoxicity [11] is demonstrated by the heterogeneity of published reports on glomerulopathy and other manifestations, including minimal change disease, collapsing glomerulopathy, membranoproliferative glomerulonephritis, focal segmental glomerulosclerosis, cryoglobulinemic glomerulonephritis, acute tubular necrosis, and interstitial nephritis [7]. Furthermore, worsening kidney disease can further exacerbate hypertension, which may perpetuate AKI [10].

Treatment for low-grade proteinuria usually includes an angiotensin-converting enzyme (ACE) inhibitor or an angiotensin receptor blocker to reduce glomerular filtration pressure, and anti-VEGF treatment can be continued providing stable proteinuria. However, proteinuria may worsen to the nephrotic range ( $>3 \mathrm{~g}$ in $24 \mathrm{~h}$ ) with nephrotic syndrome. Even after cessation of VEGF inhibitor therapy, there are documented cases of persistent proteinuria [12].

\subsection{Angiogenesis Inhibitors Post-Transplant}

The role of the VEGF pathway in the pathogenesis of post-transplant complications is poorly understood, with preliminary reports across various organ transplants showing hypothesis-generating results [13-16]. Upregulation of angiogenesis factors was associated with increased allograft vasculopathy, bronchiolitis obliterans, and recurrence of hepatocellular carcinoma in cardiac, pulmonary, and liver transplants, respectively [13,15-17]. In renal transplants, VEGF is thought to be upregulated in acute and chronic rejection, particularly associated with cyclosporine [14].

As the first VEGF inhibitor used for anti-cancer treatment, bevacizumab was approved by the United States Food and Drug Administration in 2004, and is now licensed for use in many cancers [18] (Table 1). In ovarian cancer, patients who were prior recipients of solid organ transplants or who were receiving immunosuppressive therapies were not excluded from randomized bevacizumab trials, but those with pre-existing uncontrolled hypertension or renal dysfunction based on serum creatinine $\geq 1.6 \mathrm{mg} / \mathrm{dL}$ or proteinuria $>1 \mathrm{~g}$ per $24 \mathrm{~h}$ were excluded [19-21]. Similarly, in other large randomized angiogenesis inhibitor studies across other tumor sites, prior solid organ transplant or use of immunosuppressants is not an exclusion criterion, aside from studies involving immune checkpoint inhibitors [22]. Identification of patients enrolled in large angiogenesis inhibitor trials who had received prior transplants could potentially make for an interesting post-hoc pooled analysis. 
Table 1. Food and Drug Administration approved indications for bevacizumab [18].

\begin{tabular}{|c|c|c|}
\hline Cancer & Stage & Usage \\
\hline & Metastatic, first-line & $\begin{array}{c}5 \mathrm{mg} / \mathrm{kg} \text { every two weeks with bolus IFL } \\
10 \mathrm{mg} / \mathrm{kg} \text { every two weeks with FOLFOX4 }\end{array}$ \\
\hline Colorectal & $\begin{array}{l}\text { Metastatic, recurrent after first-line } \\
\text { bevacizumab-containing regimen }\end{array}$ & $\begin{array}{c}5 \mathrm{mg} / \mathrm{kg} \text { every two weeks, or } 7.5 \mathrm{mg} / \mathrm{kg} \text { every three weeks } \\
\text { with fluoropyrimidine-irinotecan, or } \\
\text { fluoropyrimidine-oxaliplatin-based chemotherapy }\end{array}$ \\
\hline Non-squamous, non-small-cell lung & Unresectable, locally advanced, recurrent, or metastatic & $15 \mathrm{mg} / \mathrm{kg}$ every three weeks with carboplatin and paclitaxel \\
\hline Glioblastoma & Recurrent & $10 \mathrm{mg} / \mathrm{kg}$ every two weeks \\
\hline Renal cell & Metastatic & $10 \mathrm{mg} / \mathrm{kg}$ every two weeks with interferon-alfa \\
\hline Cervical & Persistent, recurrent, or metastatic & $\begin{array}{c}15 \mathrm{mg} / \mathrm{kg} \text { every three weeks with paclitaxel and cisplatin, or } \\
\text { paclitaxel and topotecan }\end{array}$ \\
\hline \multirow{3}{*}{$\begin{array}{l}\text { Epithelial ovarian, fallopian tube, or } \\
\text { primary peritoneal }\end{array}$} & III or IV, following surgical resection & $\begin{array}{l}15 \mathrm{mg} / \mathrm{kg} \text { every three weeks with carboplatin and paclitaxel } \\
\text { for up to six cycles, followed by } 15 \mathrm{mg} / \mathrm{kg} \text { every three } \\
\text { weeks as a single agent for up to } 22 \text { cycles }\end{array}$ \\
\hline & Recurrent, platinum-sensitive & $\begin{array}{c}15 \mathrm{mg} / \mathrm{kg} \text { every three weeks with carboplatin and either } \\
\text { paclitaxel (6- } 8 \text { cycles) or gemcitabine ( } 6-10 \text { cycles) followed } \\
\text { by } 15 \mathrm{mg} / \mathrm{kg} \text { every } 3 \text { weeks as a single agent }\end{array}$ \\
\hline & Recurrent, platinum-resistant & $\begin{array}{c}10 \mathrm{mg} / \mathrm{kg} \text { every two weeks with paclitaxel, pegylated } \\
\text { liposomal doxorubicin, or topotecan given weekly } \\
15 \mathrm{mg} / \mathrm{kg} \text { every three weeks with topotecan every three } \\
\text { weeks }\end{array}$ \\
\hline Hepatocellular & Unresectable or metastatic, first-line & $15 \mathrm{mg} / \mathrm{kg}$ with atezolizumab every three weeks \\
\hline
\end{tabular}

Abbreviations: $\mathrm{mg} / \mathrm{kg}=$ milligrams per kilogram; IFL = infusional fluoropyrimidine; FOLFOX4 = 5-fluorouracil, folic acid, and oxaliplatin 
Similarly, reports on angiogenesis inhibition in solid organ transplant patients remain scant in the literature, as highlighted by a review on bevacizumab toxicity by Fenoglio et al [9]. Musri et al. reported a case of colorectal cancer post-renal transplantation with baseline proteinuria, which significantly worsened on administration of intravenous 5-fluorouracil, irinotecan, oxaliplatin, and bevacizumab [23]. Cheungpasitporn et al. described two cases with renal allograft dysfunction following administration of intravitreal bevacizumab, aflibercept, or ranibizumab [24]. Doses of anti-angiogenics were lower but not specified within this report. Although neither case proved causality with anti-VEGF therapy, one was diagnosed with phospholipase A2 receptor-negative membranous nephropathy, and the second revealed acute and chronic antibody-mediated rejection with glomerular thrombi and transplant glomerulopathy. Jonkers and Buren reported a case of worsening IgA nephropathy presenting with nephrotic-range proteinuria post-renal transplantation on sorafenib [25]. These reports highlight the potential severe nephrotoxicity known to be associated with angiogenesis inhibitors; however, there remain few documented positive experiences with angiogenesis inhibitor use in the post-transplant setting. Given the prevalence of nephrotoxicity with these agents, these considerations are particularly prudent for renal transplant recipients, but reports in other organ transplants remain similarly scarce.

\subsection{Medication Interactions}

Solid organ transplant recipients frequently take maintenance immunosuppressive agents, including but not limited to corticosteroids, calcineurin inhibitors, anti-proliferative agents, and mTOR inhibitors, which are associated with various complications and drug interactions (Table 2).

Table 2. Drug-drug interactions between post-transplant immunosuppressive medications and angiogenesis inhibitors.

\begin{tabular}{|c|c|}
\hline Transplant Medication & Potential Interactions with Anti-Angiogenesis Agents [26-34] \\
\hline Cyclosporine & $\begin{array}{c}\text { Increased cyclosporine levels and subsequent toxicity due to CYP3A4 and } \\
\text { P-gp-mediated drug interactions (e.g., cabozatinib, axitinib, pazopanib, } \\
\text { sorafenib, sunitinib) }\end{array}$ \\
\hline Tacrolimus & $\begin{array}{l}\text { Increased tacrolimus levels and subsequent toxicity due to inhibition of or } \\
\text { competition with CYP3A4 metabolism and P-gp-mediated transport } \\
\text { (e.g., cabozatinib, axitinib, pazopanib, sorafenib, sunitinib) } \\
\text { Additive impairment of the renal function (e.g., cediranib, axitinib, pazopanib) } \\
\text { Increased risk of QT prolongation with other agents that prolong the QT interval } \\
\text { (e.g., cabozantinib, pazopanib, sorafenib, sunitinib) }\end{array}$ \\
\hline $\begin{array}{c}\text { Mycophenolate } \\
\text { mofetil }\end{array}$ & Exaggerated leukopenia (e.g., ramucirumab, bevacizumab, sunitinib) \\
\hline Azathioprine & Exaggerated leukopenia (e.g., ramucirumab, bevacizumab, sunitinib) \\
\hline Sirolimus & $\begin{array}{l}\text { Increased tacrolimus levels and subsequent toxicity due to inhibition of or } \\
\text { competition with CYP3A4 metabolism and P-gp-mediated transport } \\
\text { (e.g., cabozatinib, axitinib, pazopanib, sorafenib, sunitinib) } \\
\text { Additive impairment of the renal function (e.g., cediranib, axitinib, pazopanib) } \\
\text { Additive impairment of wound healing }\end{array}$ \\
\hline Everolimus & $\begin{array}{c}\text { Increased everolimus levels and subsequent toxicity due to inhibition of CYP3A4 } \\
\text { metabolism and P-gp-mediated transport (e.g., cabozantinib, pazopanib) } \\
\text { Additive impairment of the renal function (e.g., cediranib, axitinib, pazopanib) } \\
\text { Additive impairment of wound healing }\end{array}$ \\
\hline Corticosteroids & $\begin{array}{l}\text { Competitive CYP3A4 metabolism (e.g., prednisone) with other CYP3A4 substrates } \\
\text { (e.g., cabozantinib, axitinib, pazopanib, sorafenib, sunitinib) }\end{array}$ \\
\hline
\end{tabular}

Abbreviations: CYP3A4 = cytochrome P450 3A4; P-gp = P-glycoprotein.

In the case presented, tacrolimus levels were measured every few months to be within the therapeutic range; this is significant as potential drug interactions between transplant medications and angiogenesis inhibitors involve pharmacokinetic and pharmacodynamic interactions. Pharmacokinetic 
interactions typically occur due to cytochrome P450 enzyme (CYP) and P-glycoprotein (P-gp) drug transport systems [26-28], and risk of competitive metabolism as substrates for the same enzyme or transporter may increase serum levels. Axitinib and sorafenib are CYP3A4 and P-gp substrates, and cabozantinib and pazopanib are substrates and inhibitors of both enzyme systems [29-32]. Drug interactions are well-described for CYP3A4 substrates cyclosporine, tacrolimus, and sirolimus, with metabolic inhibition leading to increased immunosuppressant concentrations ( 20\%) [28]. Pharmacodynamic interactions primarily concern cumulative toxicities between these two classes (Table 2) $[26,27,33,34]$. Interestingly, Onodera et al. reported upon a case of metastatic colorectal cancer post-renal transplant where a patient was administered five cycles of 5-fluorouracil, oxaliplatin, and bevacizumab where although severe proteinuria occurred, serum tacrolimus levels were not affected throughout the course of treatment [35]. This report remains one of the only cases in the literature that demonstrates stability of immunosuppression whilst on bevacizumab post-transplant.

\subsection{Long-Term Adverse Events}

One of the leading causes of morbidity and mortality in solid organ transplant recipients is malignancy, most commonly non-melanomatous skin cancers [36]. Other malignancies such as colorectal, kidney, and cervical cancers are also prevalent in the post-transplant context, and angiogenesis inhibitors such as bevacizumab are commonly used in metastatic disease [18] (Table 1). Surveillance recommendations within transplant recipients are variable across the globe due to a paucity of robust screening trials [37]. Other long-term complications associated with organ transplantation and prolonged immunosuppressant use include cardiovascular disease, diabetes mellitus, hypertension, and infection associated with cytopenia. In the patient presented, adverse events have not outweighed benefits of ongoing treatment, but this will need close monitoring given the risk of overlapping toxicities as long-term adverse event data remain limited [3,38].

\section{Conclusions}

Whilst there are minimal data justifying that bevacizumab or other angiogenesis inhibitors are unsafe in the post-transplant setting, there is similarly scarce literature demonstrating safe administration, as in the patient presented. As life expectancy continues to improve with increasing indications for transplantation, long-term risks for malignancy with prolonged immunosuppression are increasingly relevant as a cause of mortality in solid organ transplant recipients. In patients who have undergone renal transplantation, careful consideration of treatment options with risk of nephrotoxicity and close monitoring remains paramount.

Although treating oncologists should remain vigilant about potential drug interactions and overlapping toxicities, these are not necessarily contraindications for agents such as bevacizumab. Treatment decisions should consider the best available evidence, and collating information about toxicity and tolerance from randomized trials and post-approval Phase IV studies would provide detailed information from at-risk subgroups. This calls for a stratified, inclusive approach to allow enrolment of those with chronic diseases and comorbidities in prospective trials, allowing objective assessment of the risk-benefit ratio.

Author Contributions: Conceptualization, L.K., A.M.O.; methodology, L.K., J.D.; software, L.K.; validation, L.K., J.D., J.S., A.K.; resources, L.K.; data curation, L.K., S.L., J.S.; writing-original draft preparation, L.K., J.D.; writing-review and editing, L.K., J.D., K.K., A.K., J.S., S.L., A.M.O.; visualization, L.K., K.K.; supervision, S.L., A.M.O. All authors have read and agreed to the published version of the manuscript.

Funding: This research received no external funding.

Institutional Review Board Statement: As this was a report with fewer than three patients, institutional approval was not sought as per the University Health Network Research Ethics Board guidance document on case reports.

Informed Consent Statement: Informed consent was obtained from all subjects involved in the study and written informed consent has been obtained from the patient to publish this paper. 
Data Availability Statement: Not applicable.

Conflicts of Interest: We have read and understood Current Oncology's policy on disclosing conflicts of interest and declare that we have none.

\section{Abbreviations}

$\begin{array}{ll}\text { VEGFR } & \text { vascular endothelial growth factor receptor } \\ \text { EGFR } & \text { epidermal growth factor receptor } \\ \text { FGFR } & \text { fibroblast growth factor receptor } \\ \text { PDGFR } & \text { platelet-derived growth factor receptor } \\ \text { SCF } & \text { stem cell factor } \\ \text { PI3K } & \text { phosphoinositide 3-kinase } \\ \text { AKT } & \text { protein kinase B } \\ \text { mTOR } & \text { mammalian target of rapamycin } \\ \text { RET } & \text { RET proto-oncogene } \\ \text { AXL } & \text { AXL receptor tyrosine kinase } \\ \text { TAH-BSO } & \text { total abdominal hysterectomy and bilateral salpingo-oophorectomy } \\ \text { Ca125 } & \text { cancer antigen 125 } \\ \text { U/ml } & \text { units per milliliter } \\ \text { AKI } & \text { acute kidney injury } \\ \text { CYP } & \text { cytochrome P450 } \\ \text { HGSOC } & \text { high-grade serous ovarian carcinoma } \\ \text { FOLFOX4 } & \text { 5-fluorouracil, leucovorin, and oxaliplatin } \\ \text { IFL } & \text { irinotecan, leucovorin, and 5-fluorouracil } \\ \text { P-gp } & \text { P-glycoprotein }\end{array}$

\section{References}

1. National Comprehensive Cancer Network. Ovarian Cancer (Version 1.2020). Available online: https: //www.nccn.org/professionals/physician_gls/pdf/ovarian.pdf (accessed on 31 August 2020).

2. Gurevich, F.; Perazella, M.A. Renal effects of anti-angiogenesis therapy: Update for the internist. Am. J. Med. 2009, 122, 322-328. [CrossRef]

3. Touyz, R.M.; Herrmann, S.M.; Herrmann, J. Vascular toxicities with VEGF inhibitor therapies-Focus on hypertension and arterial thrombotic events. J. Am. Soc. Hypertens. 2018, 12, 409-425. [CrossRef] [PubMed]

4. Zhang, Z.-F.; Wang, T.; Liu, L.-H.; Guo, H.-Q. Risks of proteinuria associated with vascular endothelial growth factor receptor tyrosine kinase inhibitors in cancer patients: A systematic review and meta-analysis. PLoS ONE 2014, 9, e90135. [CrossRef] [PubMed]

5. Wu, S.; Kim, C.; Baer, L.; Zhu, X. Bevacizumab increases risk for severe proteinuria in cancer patients. J. Am. Soc. Nephrol. 2010, 21, 1381-1389. [CrossRef] [PubMed]

6. Ollero, M.; Sahali, D. Inhibition of the VEGF signalling pathway and glomerular disorders. Nephrol. Dial. Transplant. 2015, 30, 1449-1455. [CrossRef] [PubMed]

7. Hanna, R.M.; López, E.; Wilson, J.; Barathan, S.; Cohen, A.H. Minimal change disease onset observed after bevacizumab administration. Clin. Kidney J. 2015, 9, 239-244. [CrossRef]

8. Hayman, S.R.; Leung, N.; Grande, J.P.; Garovic, V.D. VEGF inhibition, hypertension, and renal toxicity. Curr. Oncol. Rep. 2012, 14, 285-294. [CrossRef] [PubMed]

9. Fenoglio, R.; Roccatello, D. Bevacizumab: Renal safety evaluation. J. Onco-Nephrol. 2017, 1, $198-203$. [CrossRef]

10. Pandey, A.K.; Singhi, E.K.; Arroyo, J.P.; Ikizler, T.A.; Gould, E.R.; Brown, J.; Beckman, J.A.; Harrison, D.G.; Moslehi, J. Mechanisms of VEGF (Vascular Endothelial Growth Factor) inhibitor-Associated hypertension and vascular disease. Hypertension 2018, 71, e1-e8. [CrossRef]

11. Estrada, C.C.; Maldonado, A.; Mallipattu, S.K. Therapeutic inhibition of VEGF signaling and associated nephrotoxicities. J. Am. Soc. Nephrol. 2019, 30, 187-200. [CrossRef]

12. Izzedine, H. Anti-VEGF cancer therapy in nephrology practice. Int. J. Nephrol. 2014, 2014, 1-8. [CrossRef] [PubMed] 
13. Daly, K.P.; Seifert, M.E.; Chandraker, A.; Zurakowski, D.; Nohria, A.; Givertz, M.M.; Karumanchi, S.A.; Briscoe, D.M. VEGF-C, VEGF-A and related angiogenesis factors as biomarkers of allograft vasculopathy in cardiac transplant recipients. J. Hear. Lung Transplant. 2013, 32, 120-128. [CrossRef] [PubMed]

14. Rintala, S.; Savikko, J.; Rintala, J.; Von Willebrand, E. Vascular Endothelial Growth Factor (VEGF) ligand and receptor induction in rat renal allograft rejection. Transplant. Proc. 2006, 38, 3236-3238. [CrossRef] [PubMed]

15. Xu, H.; Abuduwufuer, A.; Lv, W.; Zhou, Z.; Yang, Y.; Zhang, C.; Hu, J. The role of HIF-1 $\alpha$-VEGF pathway in bronchiolitis obliterans after lung transplantation. J. Cardiothorac. Surg. 2019, 14, 27. [CrossRef] [PubMed]

16. Zhang, W.; Kim, R.; Quintini, C.; Hashimoto, K.; Fujiki, M.; Diago, T.; Eghtesad, B.; Miller, C.; Fung, J.F.; Tan, A.; et al. Prognostic role of plasma vascular endothelial growth factor in patients with hepatocellular carcinoma undergoing liver transplantation. Liver Transplant. 2014, 21, 101-111. [CrossRef]

17. Daly, K.P.; Stack, M.; Eisenga, M.F.; Keane, J.F.; Zurakowski, D.; Blume, E.D.; Briscoe, D.M. Vascular endothelial growth factor $\mathrm{A}$ is associated with the subsequent development of moderate or severe cardiac allograft vasculopathy in pediatric heart transplant recipients. J. Hear. Lung Transplant. 2017, 36, 434-442. [CrossRef]

18. Drugs@FDA: FDA-Approved Drugs. Available online: https://www.accessdata.fda.gov/drugsatfda_docs/ label/2020/125085s332lbl.pdf (accessed on 31 August 2020).

19. Aghajanian, C.; Goff, B.; Nycum, L.R.; Wang, Y.V.; Husain, A.; Blank, S.V. Final overall survival and safety analysis of OCEANS, a phase 3 trial of chemotherapy with or without bevacizumab in patients with platinum-sensitive recurrent ovarian cancer. Gynecol. Oncol. 2015, 139, 10-16. [CrossRef]

20. Pujade-Lauraine, E.; Hilpert, F.; Weber, B.; Reuss, A.; Poveda, A.; Kristensen, G.B.; Sorio, R.; Vergote, I.; Witteveen, P.; Bamias, A.; et al. Bevacizumab combined with chemotherapy for platinum-resistant recurrent ovarian cancer: The AURELIA open-label randomized phase III trial. J. Clin. Oncol. 2014, 32, 1302-1308. [CrossRef]

21. Oza, A.M.; Cook, A.D.; Pfisterer, J.; Embleton, A.; A Ledermann, J.; Pujade-Lauraine, E.; Kristensen, G.B.; Carey, M.S.; Beale, P.; Cervantes, A.; et al. Standard chemotherapy with or without bevacizumab for women with newly diagnosed ovarian cancer (ICON7): Overall survival results of a phase 3 randomised trial. Lancet Oncol. 2015, 16, 928-936. [CrossRef]

22. Finn, R.S.; Qin, S.; Ikeda, M.; Galle, P.R.; Ducreux, M.; Kim, T.-Y.; Kudo, M.; Breder, V.; Merle, P.; Kaseb, A.O. Atezolizumab plus bevacizumab in unresectable hepatocellular carcinoma. N. Engl. J. Med. 2020, 382, 1894-1905. [CrossRef]

23. Müsri, F.Y.; Mutlu, H.; Eryılmaz, M.K.; Salim, D.K.; Coşkun, H.Ş. Experience of bevacizumab in a patient with colorectal cancer after renal transplantation. J. Cancer Res. Ther. 2015, 11, 1018-1020. [CrossRef] [PubMed]

24. Cheungpasitporn, W.; Chebib, F.T.; Cornell, L.D.; Brodin, M.L.; Nasr, S.H.; Schinstock, C.; Stegall, M.D.; Amer, H. Intravitreal antivascular endothelial growth factor therapy may induce proteinuria and antibody mediated injury in renal allografts. Transplantation 2015, 99, 2382-2386. [CrossRef] [PubMed]

25. Jonkers, I.; van Buren, M. Nephrotic-range proteinuria in a patient with a renal allograft treated with sorafenib for metastatic renal-cell carcinoma. Clin. Exp. Nephrol. 2009, 13, 397-401. [CrossRef] [PubMed]

26. Fogli, S.; Porta, C.; Del Re, M.; Crucitta, S.; Gianfilippo, G.; Danesi, R.; Rini, B.I.; Schmidinger, M. Optimizing treatment of renal cell carcinoma with VEGFR-TKIs: A comparison of clinical pharmacology and drug-drug interactions of anti-angiogenic drugs. Cancer Treat. Rev. 2020, 84, 101966. [CrossRef] [PubMed]

27. Danovitch, G. Handbook of Transplantation (Immunosuppressive Medications and Protocols for Kidney Transplantation), 6th ed.; Lippincott Williams \& Wilkins: Philadelphia, PA, USA, 2017.

28. Gibardi, S.; Tichy, E.M. Overview of immunosuppressive therapies in renal trans-plantation. In Core Concepts in Renal Transplantation; Chandrakar, A., Sayegh, M.H., Singh, A.J., Eds.; Springer: New York, NY, USA, 2012; Available online: https:/link.springer.com/book/10.1007\%2F978-1-4614-0008-0 (accessed on 1 September 2020).

29. Pfizer Products ULC. Inlyta; [Product Monograph]; Pfizer Products ULC: Kirkland, QC, Canada, 2020.

30. Bayer Inc. Nexavar; [Product Monograph]; Bayer Inc.: Mississauga, ON, Canada, 2020.

31. Ipsen Biopharmaceuticals Canada Inc. Cabometyx; [Product Monograph]; Ipsen Biopharmaceuticals Canada Inc.: Mississauga, ON, Canada, 2020.

32. Novartis Pharmaceuticals Canada Inc. Votrient; [Product Monograph]; Novartis Pharmaceuticals Canada Inc.: Dorval, QC, Canada, 2020.

33. Enderby, C.Y.; Keller, C.A. An overview of immunosuppression in solid organ transplantation. Am. J. Manag. Care 2015, 21, S12-S23. 
34. Ghatalia, P.; Je, Y.; Kaymakcalan, M.D.; Sonpavde, G.; Choueiri, T.K. QTc interval prolongation with vascular endothelial growth factor receptor tyrosine kinase inhibitors. Br. J. Cancer 2014, 112, 296-305. [CrossRef]

35. Onodera, R.; Nihei, S.; Kimura, T.; Tomita, T.; Kudo, K. Severe proteinuria during the administration of bevacizumab plus mFOLFOX6 in a colorectal cancer patient after kidney transplantation: A case report. J. Pharm. Health Care Sci. 2020, 6, 1-5. [CrossRef]

36. Engels, E.A.; Pfeiffer, R.M.; Fraumeni, J.F.; Kasiske, B.L.; Israni, A.K.; Snyder, J.J.; Wolfe, R.A.; Goodrich, N.P.; Bayakly, A.R.; Clarke, C.A.; et al. Spectrum of cancer risk among US solid organ transplant recipients. JAMA 2011, 306, 1891-1901. [CrossRef]

37. Acuna, S.A.; Huang, J.W.; Scott, A.L.; Micic, S.; Daly, C.; Brezden-Masley, C.; Kim, S.J.; Baxter, N.N. Cancer screening recommendations for solid organ transplant recipients: A systematic review of clinical practice guidelines. Arab. Archaeol. Epigr. 2017, 17, 103-114. [CrossRef]

38. Abdel-Qadir, H.; Ethier, J.-L.; Lee, D.S.; Thavendiranathan, P.; Amir, E. Cardiovascular toxicity of angiogenesis inhibitors in treatment of malignancy: A systematic review and meta-analysis. Cancer Treat. Rev. 2017, 53, 120-127. [CrossRef]

Publisher's Note: MDPI stays neutral with regard to jurisdictional claims in published maps and institutional affiliations.

(C) 2021 by the authors. Licensee MDPI, Basel, Switzerland. This article is an open access article distributed under the terms and conditions of the Creative Commons Attribution (CC BY) license (http://creativecommons.org/licenses/by/4.0/). 